\title{
Hypothyroidism and Glucocorticoids Modulate the Development of Hepatic Insulin Receptors
}

\author{
BRUCE M. STERMAN, SUPRIYA GANGULI, SHERIN DEVASKAR, AND MARK A. SPERLING ${ }^{(32)}$ \\ Department of Pediatrics, Division of Endocrinology, Children's Hospital Medical Center, Cincinnati, Ohio, USA
}

\begin{abstract}
Summary
We investigated the influence of hypothyroidism and of glucocorticoid treatment on the in utero and postnatal maturation of insulin receptors on partially purified liver plasma membranes of the rabbit. Treatment of pregnant does with propylthiouracil (PTU) $200 \mathrm{mg} /$ day plus thyroxine (T4) $20 \mu \mathrm{g}$ on alternate days resulted in fetal but not maternal hypothyroidism because PTU crosses the placenta whereas T4 does not (fetal free T4 undetectable compared to control of $0.21 \pm 0.012 \mathrm{ng} / \mathrm{dl}$; mean \pm S.E.). At 28 days of gestation (term $\sim 31$ days), insulin binding and receptor number of hypothyroid animals was only $50 \%$ of that found in controls $(P<0.01)$. Intramuscular injection of betamethasone $(0.085 \mathrm{mg} / \mathrm{kg})$ to mothers on days 25 and 26 of gestation suppressed fetal corticosterone concentration at day 28 of gestation from $10.5 \pm 1.5 \mathrm{ng} / \mathrm{ml}$ (mean \pm S.E.) in controls to $2.1 \pm 0.28 \mathrm{ng}$ / $\mathrm{ml}(P<0.01)$; insulin binding and receptor number was $\sim 50 \%$ of controls $(P<0.01)$.

Using the two-site receptor model, the decrease in receptor number induced by hypothyroidism and glucocorticoids was due solely to reduction in the number of low-affinity sites without any change in the high affinity sites or affinity constants of either receptor class. Ongoing treatment with PTU for 6 postnatal days produced persistant hypothyroidism (free T4 $0.15 \pm 0.1 \mathrm{ng} / \mathrm{dl}$ versus control $0.73 \pm 0.1 \mathrm{ng} / \mathrm{dl}, P<0.01$ ) physical signs of immaturity, and prevented the normal postnatal maturation of insulin receptor characteristics. Insulin binding was reduced ( $P$ $<0.02$ ) and the proportion of high and low affinity receptor sites remained similar to those of 28 -day-old fetuses. In contrast, normal maturational changes in insulin receptor characteristics were evident on day 6 in the liver membranes of animals simultaneously receiving PTU and replacement T4 (free T4 $0.63 \pm 0.17$ versus control $0.73 \pm 0.1 \mathrm{ng} / \mathrm{dl}$ ). Thus, the normal pattern of hepatic insulin receptor development can be modulated by hypothyroidism and glucocorticoid exposure.
\end{abstract}

\section{Abbreviations}

LPM, liver plasma membrane

PTU, propylthiouracil

Recent studies demonstrate considerable differences in the characteristics of insulin receptors of fetal and neonatal tissues when compared to their adult counterparts (13). In general, the concentration and/or affinity of insulin receptors of fetal and newborn tissues are greater than those of adult. In contrast to adult tissue, fetal insulin receptor number is not decreased by chronic exposure to high ambient insulin concentration, i.e., "down-regulation" does not occur $(13,16)$. Because, the metabolic effects of insulin are mediated initially by binding to these specific tissue receptors (19), the increased number or affinity of fetal/neonatal insulin receptors may mediate fetal anabolic processes and growth; their failure to down-regulate in the presence of hyperinsulinemia may explain the exaggerated growth of infants born to diabetic mothers $(13,16)$.
Hormones that antagonize insulin action do so in part by modulating insulin receptor characteristics. In adult tissues, glucocorticoids reduce insulin receptor number, affinity or both (8). The thyroidal status modulates insulin action (4), as well as insulin receptor number on adipocytes (11). Hypothyroidism in utero modifies the postnatal maturation of beta adrenergic receptors (31) but the effects of hypothyroidism or glucocorticoids on the development of fetal/neonatal insulin receptors are not known. Because insulin influences the growth and maturation of fetal enzymes and tissues (26), which may be modified by both hypothyroidism and glucocorticoids (5), we investigated their effects on the maturation of insulin receptors in fetal/neonatal rabbit liver.

\section{MATERIALS AND METHODS}

Fetal study. Pregnant New Zealand rabbits of known gestation (term $\sim 31$ days) were randomly assigned to one of three groups. A control group of animals $(N=4)$ were given an injection of normal saline of $0.1 \mathrm{ml}$ on day 25 and 26 of gestation. They were allowed standard diet and drinking water ad libitum. In a second group of animals $(N=6)$, the fetuses were rendered hypothyroid by treating the mothers with both propylthiouracil (PTU) and thyroxine (T4). PTU was added to the drinking water at a final concentration of $0.05 \%$; animals consumed approximately $400 \mathrm{ml}$ a day so that their total daily PTU dose was approximately 200 mg. In addition, the mothers also received $\mathrm{T} 4$ replacement at a dose of $5 \mu \mathrm{g} / 100 \mathrm{cc}$ of drinking water every other day until sacrificed. This regimen was used to produce hypothyroidism in the fetus while the mother remained euthyroid, because PTU crosses the placenta whereas $\mathrm{T} 4$ does not $(5,9)$. In the third group $(N=5)$, the mothers received an intramuscular injection of betamethasone at $0.085 \mathrm{mg} / \mathrm{kg}$ on day 25 and 26 of gestation. This dose is comparable to that used for prevention of hyaline membrane disease in humans and has been used in rabbits to produce changes in the beta-adrenergic receptors or insulin receptors of the fetal lung (5).

Immediately before sacrifice on day 28 , maternal arterial blood was collected and aliquots placed in plain glass tubes and in chilled tubes containing EDTA and aprotinin, $0.1 \mathrm{ml}$ (1000 KIU). Mothers then underwent Caesarian section; the fetuses were quickly removed and their livers rapidly excised, all livers from a single pregnancy being pooled in chilled $1 \mathrm{mM}$ bicarbonate buffer. From each fetus, blood was obtained by decapitation and the blood from all fetuses in a single litter was pooled in two separate aliquots as described above. Separation of serum or plasma was immediately carried out by centrifugation at $0^{\circ} \mathrm{C}$.

Liver plasma membranes were prepared by following the method of Neville et al. through step $11(18,28)$. Briefly, the livers were hand homogenized by eight strokes in a dounce glass homogenizer containing chilled $1 \mathrm{mM}$ bicarbonate buffer. The homogenate was diluted with buffer and strained through four layers of gauze. An aliquot of the crude homogenate was snap frozen in dry ice/acetone and stored at $-80^{\circ} \mathrm{C}$ for subsequent comparison of enrichment in membrane markers. The remainder of the crude 
homogenate was centrifuged at $1500 \times g$ for $15 \mathrm{~min}$. After aspirating the supernatant, the pellet was mixed with $69 \%$ sucrose and adjusted to a final concentration of $44 \%$ sucrose. A solution of sucrose at $42.3 \%$ was then layered on top of the $44 \%$ sucrosemembrane mixture in a cellulose acetate tube and centrifuged at $90,000 \times g$ in a refrigerated ultracentrifuge for $2 \mathrm{~h}$. The float was resuspended in chilled $1 \mathrm{mM}$ bicarbonate buffer and again centrifuged at $25,000 \times g$ for $15 \mathrm{~min}$. The final pellet, free of sucrose and fat, was then hand homogenized in buffer to yield a final concentration of protein at $2-5 \mathrm{mg} / \mathrm{ml}$. Protein concentration was measured by the method of Lowry (15) using bovine serum albumin as standard. The membranes were snap frozen in dry ice/ acetone and stored at $-80^{\circ} \mathrm{C}$ until further analysis.

Neonatal study. In order to investigate the potential influence of hypothyroidism or glucocorticoid exposure in utero on the postnatal developmental pattern of insulin receptors of liver plasma membranes, a further four groups of date-bred pregnant rabbits were studied. As before, the control group $(N=4)$ had standard diet and drinking water ad libitum. The second group $(N=5)$ had PTU solution, $0.05 \%$ added to drinking water from day 23 on. Mothers received replacement with thyroxine at $5 \mu \mathrm{g} / 100 \mathrm{cc}$ of water on alternate days. In the third group $(N=5)$, the mothers received PTU and T4 replacement as above and in addition, the newborn pups received thyroxine replacement at $15 \mathrm{ng} / \mathrm{g} /$ day injected subcutaneously on the second through the sixth day after birth. In a fourth group of animals $(N=5)$, the mothers were treated with betamethasone as described above and no further steroid treatment was provided after birth.

All the newborn pups remained in their mother's care until sacrifice on the sixth postpartum day. Immediately before sacrifice, blood samples were collected as described above. After sacrifice, the livers were rapidly removed and prepared as described above except that each pup's liver was individually prepared rather than pooled. To compare the results of the fetus and newborn with adult, five nonpregnant adult female New Zealand rabbits were used.

Insulin binding assay. Monoiodinated $\left[{ }^{125} \mathrm{I}\right]$-insulin was prepared according to the method of Sodoyez et al. (24) to a specific activity of $100-150 \mathrm{mCi} / \mathrm{mg}$. Binding assays were performed in triplicate using $50 \mu \mathrm{g}$ of membrane protein incubated at $4^{\circ} \mathrm{C}$ for $16 \mathrm{~h}$. The assay tubes contained approximately $25,000 \mathrm{cpm}$ of monoiodinated insulin, $1 \%$ bovine serum albumin and unlabeled insulin $0-10^{-7} \mathrm{M}$ in $50 \mathrm{mM}$ Tris- $\mathrm{HCl}$ buffer, $\mathrm{pH} 7.6$ in a total incubation volume of $300 \mu \mathrm{l}$. Nonspecific binding was defined as residual radioactivity after incubation with $10^{-7} \mathrm{M}$ insulin and subtracted from each point. In addition, the degradation of insulin in the system was tested by trichloracetic precipitability at the conclusion of the assay. The binding data were plotted according to Scatchard (22); these curvilinear plots were resolved into two components by a programmable calculator as described by Thakur et al. (30).

Membrane characteristics. Glucose-6-phosphatase activity was determined by the method of Baginski et al. (1) using $25 \mathrm{mM}$ cocodylate buffer with $62.5 \mathrm{mM}$ sucrose, $0.25 \mathrm{mM}$ EDTA, $25 \mathrm{mM}$ glucose-6-phosphate and $100 \mu \mathrm{g}$ of membrane protein. The duplicate assay tubes were incubated for $30 \mathrm{~min}$ at $37^{\circ} \mathrm{C}$ with shaking, the reaction terminated with $10 \%$ trichloroacetic acid followed by centrifugation at $1500 \times g$ for $15 \mathrm{~min}$. The supernatant was used for colorimetric determination of free phosphate. The reagent blank differed in that the protein was added after following the trichloroacetic acid. The water blank and phosphate standards were run along with the samples.

For the phosphate determination, $1 \mathrm{ml}$ of supernatant was mixed with $1 \mathrm{ml}$ of $1 \%$ ammonium molybdate and thoroughly mixed. After $30 \mathrm{sec}, 1 \mathrm{ml}$ of $2 \%$ arsenite-citrate was added. The assay tubes were allowed to stand for $15 \mathrm{~min}$ and absorbance measured by a spectrophotometer at a wave length of $700 \mathrm{~nm}$.

$5^{\prime}$ Nucleotidase activity was determined by the method of Dixon and Purdom (7). Five $\mathrm{mM}$ Na AMP substrate was prepared using $0.1 \mathrm{M}$ glycine buffer with $0.02 \mathrm{M} \mathrm{MgCl}, \mathrm{pH} 9.1$, and $100 \mu \mathrm{g}$ of membrane protein. The assay was performed in duplicate and incubated at $37^{\circ} \mathrm{C}$ with shaking for $15 \mathrm{~min}$. The reaction was terminated with $10 \%$ trichloroacetic acid and the tubes centrifuged at $1500 \times g$ for $15 \mathrm{~min}$. The supernatant was assayed for phosphate as above.

Plasma glucose was measured by the glucose oxidase method using a Yellow Springs Instrument and plasma insulin (27) or plasma corticosteroids (6) were measured by radioimmunoassay. Free T4 was measured by the Amerlex free T4 RIA kit (Amersham Corporation, IL). The normal range in euthyroid humans in our laboratory is $1.21 \pm 0.21 \mathrm{ng} / \mathrm{dl}$ (mean \pm S.D.) and compares favorably with the manufacturer's normal range of $0.8-1.8 \mathrm{ng} / \mathrm{dl}$. Normal free $\mathrm{T} 4$ values in rabbits have not been defined by this method.

All data are represented as mean \pm S.E. of the mean. Statistical significance was determined by the two-tailed Student's $t$ test and where appropriate by analysis of variance.

\section{RESULTS}

Fetal studies. Table 1 lists the body weight, liver weight, and hormone concentrations among the three groups. Neither hypothyroidism nor glucocorticoid exposure significantly influenced fetal body weight or liver weight when compared to the control group. Similarly, serum glucose and insulin values were not significantly different among the three fetal groups; however, serum free $\mathrm{T} 4$ concentration was markedly suppressed from 0.21 $\pm 0.012 \mathrm{ng} / \mathrm{dl}$ in the controls to undetectable levels in the PTU treated group. Mothers treated with PTU plus T4 remained euthyroid with free $\mathrm{T} 4$ of $0.29 \pm 0.09 \mathrm{ng} / \mathrm{dl}$ compared to the control mothers free $\mathrm{T} 4$ of $0.28 \pm 0.09 \mathrm{ng} / \mathrm{dl}$. Betamethasone treatment significantly reduced the fetal serum corticosterone concentration from $10.5 \pm 1.5 \mathrm{ng} / \mathrm{ml}$ to $2.1 \pm 0.28 \mathrm{ng} / \mathrm{ml}$ and maternal corticosterone from $55 \pm 7 \mathrm{ng} / \mathrm{ml}$ to $4.4 \pm 0.8 \mathrm{ng} / \mathrm{ml}$; corticosterone concentration was not affected by hypothyroidism in either fetus or mother.

Membrane characteristics are listed in Table 2. Purification did not influence glucose-6-phosphatase activity in either the adult or fetal membranes, although fetal membrane activity was significantly less than that observed in the adult. $5^{\prime}$ Nucleotidase activity was enriched 2-fold in the adult and approximately 4-fold in the fetus but there were no significant differences between fetal and adult membrane. Similarly, specific binding of $\left[{ }^{125} \mathrm{I}\right]$-insulin per $50 \mu \mathrm{g}$ of protein was increased 3-5-fold in the partially purified membranes when compared to the crude homogenate. Degradation of $\left[{ }^{125} \mathrm{I}\right]$-insulin by crude membranes was inhibited by bacitracin $2 \mathrm{mg} / \mathrm{ml}$ and aprotinin, $500 \mathrm{KIU} / \mathrm{ml}$.

The influence of hypothyroidism and glucocorticoids on insulin binding and insulin receptor characteristics is illustrated in Table 3 and Figure 1. Both hypothyroidism and glucocorticoids reduced specific insulin binding by approximately $50 \%$ as well as reducing total receptor number by approximately $50 \%$ ( $P<0.01$ for each). Using the two receptor site model (high affinity-low capacity; low affinity-high capacity), the decrease in receptor number induced by hypothyroidism and glucocorticoid exposure can be attributed to a halving of the number of low affinity receptor sites $\left(\mathbf{R}_{2}\right.$-Table 3 ), whereas the high-affinity receptor number remains constant. Neither the average affinity nor the affinities of the high or low affinity sites were influenced by hypothyroidism or glucocorticoids.

Neonatal studies. None of the glucocorticoid treated animals survived to 6 days of life.

Body weight was significantly higher in the control newborns at 6 days of life than in either the hypothyroid animals (PTU treated), or the hypothyroid animals restored to euthyroidism by supplemental T4 therapy (Table 1). Although liver weights did not differ among the three groups, there were external signs of immaturity in the hypothyroid animals manifested by decreased activity and a decrease in the rate of body hair growth. Treatment with PTU prevented the normal neonatal surge of free T4 so that hypothyroid animals had free T4 concentrations significantly lower than those of control animals; treatment with replacement T4 restored free T4 concentrations to the normal range. Serum 
Table 1. Effect of treatment on physical characteristics and hormone levels ${ }^{1}$

\begin{tabular}{|c|c|c|c|c|c|c|}
\hline & $\begin{array}{l}\text { Body weight } \\
\text { (g) }\end{array}$ & $\begin{array}{l}\text { Liver weight } \\
(\mathrm{g})\end{array}$ & $\begin{array}{l}\text { Glucose } \\
(\mathrm{mg} / \mathrm{dl})\end{array}$ & $\begin{array}{l}\text { Corticosterone } \\
(\mathrm{ng} / \mathrm{ml})\end{array}$ & $\begin{array}{l}\text { Free } \mathrm{T}_{4} \\
(\mathrm{ng} / \mathrm{dl})\end{array}$ & $\begin{array}{l}\text { Insulin } \\
(\mu \mathrm{U} / \mathrm{ml})\end{array}$ \\
\hline \multicolumn{7}{|l|}{ Fetal studies } \\
\hline 28 day control $(N=4)^{2}$ & $28.3 \pm 2.7$ & $1.9 \pm 0.5$ & $58 \pm 6$ & $10.5 \pm 1.5$ & $0.21 \pm .012$ & $78.1 \pm 17.6^{4}$ \\
\hline 28 day propylthiouracil treated $(N=6)$ & $32.6 \pm 1.9$ & $2.6 \pm 0.3$ & $51 \pm 8$ & $12.5 \pm 1.9$ & Undetectable $^{3}$ & $40.0 \pm 6.8^{4}$ \\
\hline 28 day glucocorticoid treated $(N=5)$ & $26.9 \pm 0.6$ & $2.3 \pm 0.2$ & $55 \pm 5$ & $2.1 \pm .28^{3}$ & & $72.9 \pm 13.7^{4}$ \\
\hline \multicolumn{7}{|l|}{ Neonatal studies } \\
\hline 6 day control $(N=4)$ & $122.5 \pm 7.4$ & $3.9 \pm 0.5$ & $59 \pm 2$ & & $0.73 \pm 0.10$ & $17.8 \pm 4.8^{5}$ \\
\hline 6 day propylthiouracil treatment $(N=5)$ & $96.2 \pm 5.4^{3}$ & $4.0 \pm 0.3$ & $55 \pm 1$ & & $0.15 \pm 0.10^{3}$ & $28.4 \pm 9.5^{5}$ \\
\hline $\begin{array}{l}6 \text { day propylthiouracil and thyroxine treat- } \\
\text { ment }(N=5)\end{array}$ & $88.4 \pm 7.9^{3}$ & $3.0 \pm 0.4$ & $48 \pm 6$ & & $0.63 \pm 0.17$ & $18.0 \pm 5.9^{5}$ \\
\hline
\end{tabular}

${ }^{1}$ All data are mean \pm S.E.

${ }^{2}$ In fetal studies, $n$ is the number of individual litters pooled. In neonatal studies, $n$ is the number of individual animals.

${ }^{3} P<0.05$ c.f. controls.

${ }^{4}$ Human insulin standard.

${ }^{5}$ Rat insulin standard.

Table 2. Characteristics of rabbit liver plasma membranes ${ }^{1}$

\begin{tabular}{|c|c|c|c|c|}
\hline \multirow[b]{2}{*}{ Marker } & \multicolumn{2}{|c|}{ Adult } & \multicolumn{2}{|c|}{ Fetus $^{2}$} \\
\hline & Crude homogenate & Partially $^{3}$ purified & Crude homogenate & Partially $^{3}$ purified \\
\hline $\begin{array}{l}\text { Glucose-6-phosphatase } \\
\quad\left(\mu \text { mole } \mathrm{PO}_{4} / \mathrm{mg} \text { protein } / \mathrm{hr}\right)\end{array}$ & $3.03 \pm 0.42$ & $4.4 \pm 0.76$ & $1.14 \pm 0.42$ & $1.41 \pm 0.18$ \\
\hline $\begin{array}{l}5^{\prime} \text {-Nucleotidase } \\
\quad\left(u \text { mole } \mathrm{PO}_{4} / \mathrm{mg} \text { protein } / \mathrm{hr}\right)\end{array}$ & $0.35 \pm 0.03$ & $0.77 \pm 0.21^{4}$ & $0.26 \pm 0.05$ & $0.97 \pm 0.33^{4}$ \\
\hline $\begin{array}{l}\text { Specific binding of }\left[{ }^{125} \mathbf{I}\right] \text {-insulin } \\
\text { (per } 50 \mu \mathrm{g} \text { protein) }\end{array}$ & $8.6 \pm 1.5$ & $24.5 \pm 2.2^{5}$ & $5.6 \pm 1.0$ & $25.6 \pm 3.0^{5}$ \\
\hline
\end{tabular}

${ }^{1}$ All values are mean \pm S.E.; $N=5$ per group.

${ }^{2}$ Fetal membranes were prepared from pooled litters at 28 day gestation.

${ }^{3}$ Partially purified membranes represent step 11 of Neville preparation (ref. 17).

${ }^{4} P<0.05$ compared to crude homogenate.

${ }^{5} P<0.01$ compared to crude homogenate.

Table 3. Insulin receptor characteristics in fetal rabbit liver plasma membranes $(L P M)^{1}$

\begin{tabular}{|c|c|c|c|c|c|c|c|}
\hline \multirow{2}{*}{$\begin{array}{l}\text { Groups } \\
(N)\end{array}$} & \multicolumn{3}{|c|}{$\begin{array}{l}\text { Affinity constant } \\
\qquad\left(10^{8} \mathrm{M}^{-1}\right)\end{array}$} & \multicolumn{3}{|c|}{$\begin{array}{l}\text { Receptor } / 50 \mu \mathrm{g} \text { LPM protein } \\
\left(10^{-10} \mathrm{M} / \text { liter }\right)\end{array}$} & \multirow{2}{*}{$\begin{array}{c}\text { \% Specific binding } \\
\text { of }\left[{ }^{125} \mathrm{I}\right] \text {-insulin } \\
\text { per } 50 \mu \mathrm{g} \text { LPM protein }\end{array}$} \\
\hline & $\overline{\mathrm{Ke}}$ & $\mathrm{K}_{1}$ & $\mathrm{~K}_{2}$ & $\mathbf{R}_{0}$ & $\mathrm{R}_{1}$ & $\mathrm{R}_{2}$ & \\
\hline Fetus 28 day control (4) & $4.86 \pm 0.30$ & $34.1 \pm 3.0$ & $2.07 \pm 0.29$ & $7.01 \pm 0.92$ & $0.63 \pm 0.14$ & $6.38 \pm 0.87$ & $25.6 \pm 3.0$ \\
\hline $\begin{array}{l}\text { Fetus } 28 \text { day propylthio- } \\
\text { uracil treated (6) }\end{array}$ & $5.15 \pm 0.69$ & $33.6 \pm 4.8$ & $1.80 \pm 0.19$ & $3.33^{4} \pm 0.30$ & $0.52 \pm 0.09$ & $3.01^{4} \pm 0.35$ & $15.1^{4} \pm 1.1$ \\
\hline $\begin{array}{l}\text { Fetus } 28 \text { day glucocorticoid } \\
\text { treated }(5)\end{array}$ & $5.37 \pm 0.52$ & $25.4 \pm 3.8$ & $1.43 \pm 0.25$ & $2.76^{4} \pm 0.29$ & $0.47 \pm 0.06$ & $2.30^{4} \pm 0.29$ & $12.1^{4} \pm 0.96$ \\
\hline
\end{tabular}

${ }^{1}$ All values are mean \pm S.E.

${ }^{2} \overline{\mathrm{K}}$ represents average affinity; $\mathrm{K}_{1}$ represents high-affinity receptor; and $\mathrm{K}_{2}$ represents low-affinity receptor.

${ }^{3} R_{0}$ represents total receptor number; $R_{1}$ represents high affinity sites; and $R_{2}$ represents low affinity sites.

${ }^{4} P<0.01$ compared to 28 day fetal control.

insulin and glucose concentrations did not differ among the three groups.

Table 4 and Figure 2 lists the specific binding and insulin receptor characteristics of the newborn animals and compares them to the results obtained in the control fetal animals as well as in adult nonpregnant controls. Hypothyroidism significantly reduced specific insulin binding whereas restoration of euthyroidism in these PTU-treated animals restored insulin binding to that observed in controls; thus, hypothyroidism per se was responsible for the reduction in insulin binding. Analysis of the binding data by the high/low affinity receptor site model revealed that the reduction in total binding was due to a reduction in the number of high affinity receptor sites in the hypothyroid animals whereas total receptor number and low affinity receptor sites were unaltered. Comparison of the receptor characteristics in the newborn and fetal control animals revealed that there had been a substantial shift in the proportions of high and low affinity receptor sites; in the newborn control animals, low affinity receptor number was halved whereas high affinity receptor number had doubled. This normal maturational pattern did not occur in the hypothyroid animals, which still had receptor characteristics similar to those observed in utero without the increase in high affinity receptor number. In contrast, normal maturational changes in receptor characteristics were evident in the PTU-treated animals, which also received T4. Hypothyroidism prevented the normal postnatal maturation of insulin receptor characteristics predominantly by preventing the normal increase of high affinity receptor sites. Affinity constants were not affected by hypothyroidism but in comparison to the fetal controls, average affinity had increased significantly in all neonatal groups. In addition, average affinity and the affinity constant for the high affinity sites was significantly greater in newborn animals when compared to adult controls. 

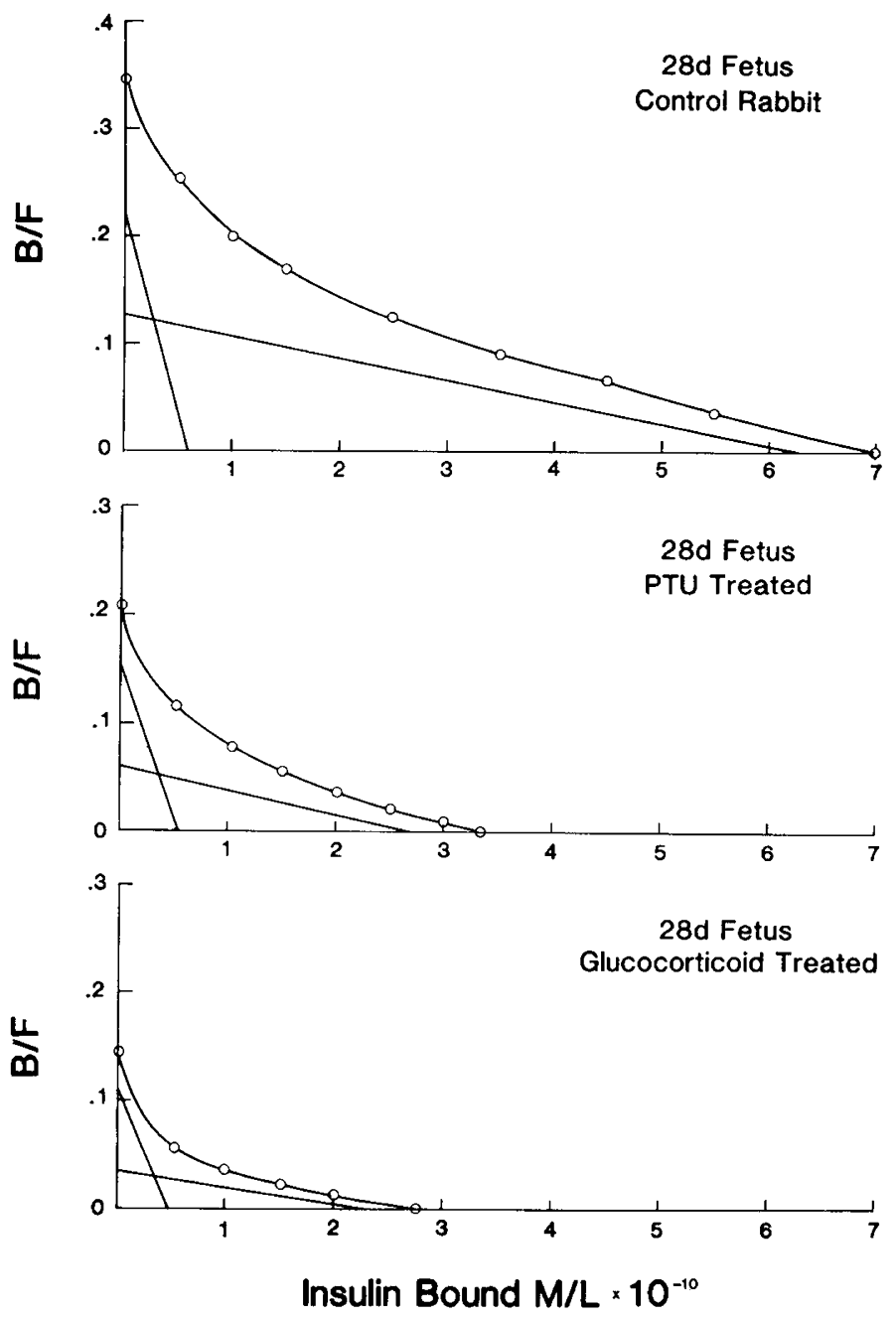

Fig. 1. Scatchard plots of insulin binding to partially purified liver plasma membranes from fetal rabbits at 28 days gestation (term $\sim 31$ days). Propylthiouracil (PTU) treated animals were documented as being hypothyroid, whereas glucocorticoid-treated animals were documented to have suppression of endogenous steroid production (see text and Table 1 for details). Each Scatchard plot has been resolved according to the two site model into high and low affinity components. Both hypothyroidism and glucocorticoid exposure in utero decrease binding $(B / F)$ and total receptor number in comparison to the control animals (see Table 3 and text for details).

\section{DISCUSSION}

The present studies in rabbits demonstrate that the normal pattern of insulin receptor development in liver can be modulated by hypothyroidism and glucocorticoid exposure.

Although total receptor number and insulin binding per $50 \mu \mathrm{g}$ of membrane protein was not greater in the 28-day-old control fetal or 6-day-newborn control animals when compared to adult, the results must be interpreted in the context of the rapid changes in insulin receptor characteristic that occur during the last few days of gestation. We have previously demonstrated a 3 -fold increase in insulin binding and total receptor number in liver membranes from 27-30-day-old fetal rabbits when compared to 25-26-day-old fetuses (10). Similarly, in rat liver, there is a sharp increase in insulin binding and receptor number between day 18 and term at approximately day 21 , and values at day 18 are comparable to those of adult rat liver (17). After birth, insulin receptor number declines in various species, so that the values by 6 days may again be similar to those of adult (13); however, in accord with previous studies, the affinity of fetal/neonatal insulin receptors are higher than those of adult, especially those of the high-affinity sites $(5,13,16,17)$. In addition, our data indicate that normal late fetal, or early postnatal maturation of insulin receptors in liver involves major changes in affinity and proportion of receptor types; average affinity doubles at 6 days in comparison to the 28-day-old fetus and is accompanied by a doubling of high affinity sites with a proportional decrease in low affinity sites. These changes cannot be attributed to differences in membrane purity because we demonstrate similar membrane characteristics in fetal and adult liver membranes and a similar enhancement of membrane marker activity during our purification procedure.

Hypothyroidism modulates these normal developmental patterns both in utero and in the newborn period. Treatment of mothers with PTU plus thyroxine for 5 days clearly induced fetal hypothyroidism as reflected in the undetectable concentration of fetal free T4; maternal euthyroidism was maintained. Although total body weight and liver weight were not affected by hypothyroidism, effects on tissue or enzyme differentiation cannot be excluded; human newborns with documented hypothyroidism may be large for gestational age yet manifest immaturity in tissue or enzyme maturation $(5,9)$. Although hypothyroidism did not alter serum insulin concentration, insulin binding and receptor number was halved from values found in gestational controls. Furthermore, this decrease exclusively affected the number of low affinity sites without affecting the affinity constants. Perpetuation of hypothyroidism in the first 6 days of life was again documented by the significantly lower free $\mathrm{T} 4$ concentration in these animals compared to their normal controls. Body weight was significantly reduced and there were other signs of immaturity; decreased activity, decreased hair growth, and decreased ear size. Although liver weight was not affected, binding of insulin was significantly reduced and the normally occurring postnatal increase in high affinity sites was prevented. The specificity of these effects being due to hypothyroidism rather than to PTU was clearly demonstrated because a similar group of PTU-treated animals restored to euthyroidism by daily $\mathrm{T} 4$ administration manifested the normal postnatal maturational pattern of insulin binding and receptor characteristics by 6 days of life as well as normal physical maturity. Failure of these two groups of animals to gain weight normally may be due to the frequent handling to which they were subjected during the first 6 days of life; control animals were not handled until the 6th postnatal day. Similar effects of hypothyroidism in delaying the normal postnatal maturation of beta adrenergic receptors in lung has recently been reported (31). Hypothyroidism also diminishes the number of functional glucagon receptors in adult liver (28) and adrenergic receptors of various adult tissue (29), whereas hyperthyroidism increases the number of insulin receptors of rat adipocytes (11).

Administration of betamethasone to mothers suppressed fetal corticosterone, demonstrating the effectiveness and transplancental passage of the administered steroid. Although glucocorticoids at the doses used enhance surfactant synthesis and the maturation of other enzyme systems in experimental animals and man $(5,14$, $21,25)$, betamethasone may also induce runting or other inhibitory effects on fetal development in the rabbit (2). In our studies, betamethasone administration for several days did not impair body or liver weight at 28 days gestation; however, none of the animals so treated survived during the first 6 days of life, precluding investigation of their insulin receptor characteristics postnatally.

In utero, betamethasone exposure resulted in a halving of insulin binding and receptor number, affecting exclusively low affinity receptor sites whereas receptor affinity constants of either class of receptors was not affected. Despite augmentation of certain enzyme systems $(5,14,21,25)$, glucocorticoids impair the development of insulin receptors in fetal rabbit liver. Similar effects of glucocorticoids in reducing insulin receptors have been reported in adult rat adipocyte, hepatocyte and liver plasma membrane $(8$, $12,20)$. The effects of glucocorticoids on insulin receptors appear to depend, in part, on the steroid used and the tissue examined (3, 
Table 4. Insulin receptor characteristics in fetal, newborn and adult rabbit liver plasma membranes ${ }^{1}$

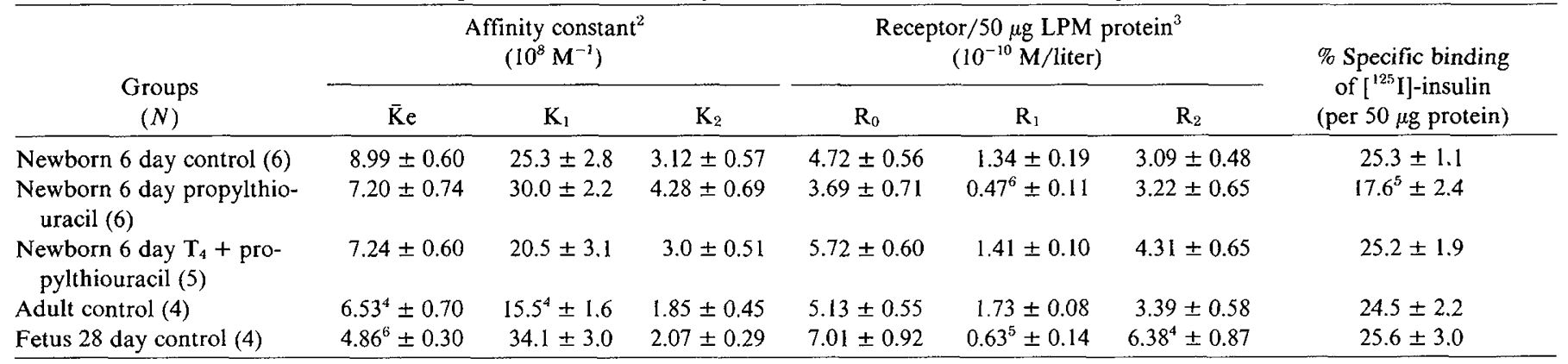

${ }^{1}$ All values are mean \pm S.E.

${ }^{2}$ For definition of $\mathrm{Ke}, \mathrm{K}_{1}$, and $\mathrm{K}_{2}$, see footnote 2 of Table 3 .

${ }^{3}$ For definition of $R_{0}, R_{1}$, and $R_{2}$, see footnote 3 of Table 3 .

${ }^{4} P<0.05$ compared to 6 day control.

${ }^{5} P<0.02$ compared to 6 day control.

${ }^{6} P<0.01$ compared to 6 day control.
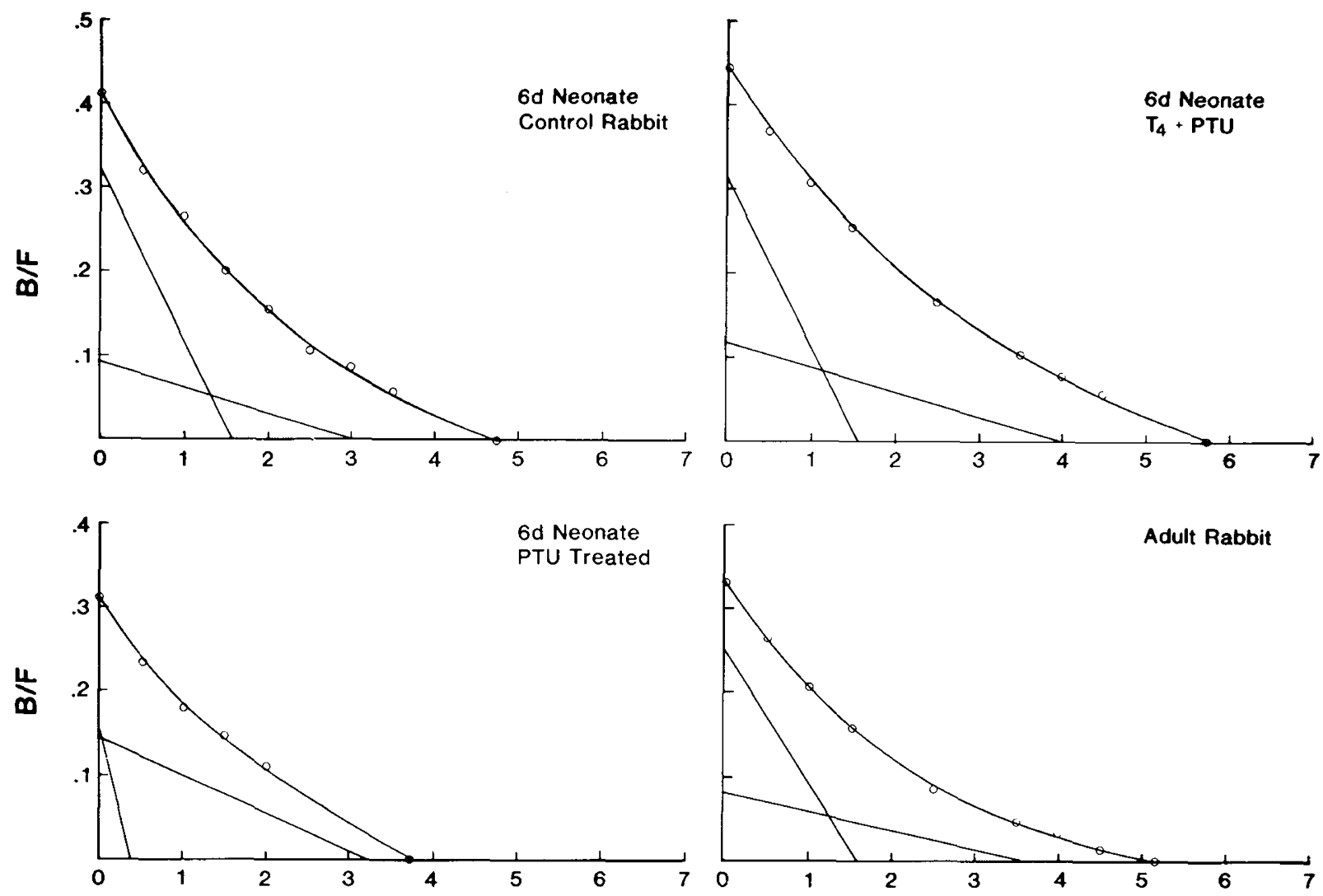

Insulin Bound $M / L \times 10^{10}$

\section{Insulin Bound $\mathrm{M} / \mathrm{L} \cdot 10^{10}$}

Fig. 2. Scatchard plots of insulin binding to partially purified liver plasma membranes from newborn rabbits on day 6 of life and from nonpregnant adult. Propylthiouracil (PTU) treated animals were documented as being hypothyroid (bottom left panel) whereas treatment with PTU plus T4 (top right panel) restored euthyroidism (see Table 1 and text for details). Each plot has been resolved according to the two-site model into high and low affinity components. Hypothyroidism prevents the normal maturation of insulin receptors; euythyroidism restores maturation of receptors to that found in controls (see Table 4 and text for details).

$8,23)$; prednisone had no effect on insulin receptors of adipocytes (3) and cortisol no effect on insulin receptors of human monocytes (23). The specificity of betamethasone in reducing the number of liver insulin receptors in our studies is highlighted by the fact that betamethasone at the same dose had the opposite effect on the fetal rabbit lung in which insulin receptors increase after exposure to this steroid (5).

Whether the effects of hypothyroidism and glucocorticoids on impairing insulin receptor development have biologic significance cannot be determined from the present study; however, insulin mediates many fetal growth processes (26) and insulin receptors are widely distributed in tissues including brain (19). The changes in insulin receptor number and characteristics induced by hypothyroidism and glucocorticoid exposure, in the absence of changes in fetal insulin concentration, suggest that insulin would be less effective in promoting fetal growth processes. Some of the inhibitory effects of hypothyroidism and glucocorticoid on the growth and maturation of fetal tissues, including the brain (9), may be mediated, in part, by their effects on the normal maturation of insulin receptors in these tissues. 


\section{REFERENCES AND NOTES}

1. Baginski, E. S., Foa, P. P., and Zak, B.: Glucose-6-Phosphatase In: Bergmeyer, H. U. (Ed) Methods of Enzymatic Analysis. Vol. 2. p. 876. (Acad. Press. Inc. New York, 1974).

2. Barrada, M. I., Blomqvist, C. H., and Knotts, C.: The effects of betamethasone on fetal development in the rabbit. Am. J. Obs. Gynecol., 136: 234 (1980).

3. Bennett, G. V., and Cuatrecasas, P.: Insulin receptors of fat cells in insulin resistant metabolic states. Science, 176: 805 (1972).

4. Czech, M. P., Malbon, C. C., Kerman, K., Gitomer, W., and Pilch, P. F.: Effect of thyroid status on insulin action in rat adipocytes and skeletal muscle. $J$. Clin. Invest., 66: 574 (1980).

5. Devaskar, S. U., Ganguli, S., Devaskar, U. P., and Sperling, M. A.: Glucocorticoids and hypothyroidism modulate development of fetal lung insulin receptors. Am. J. Physiol., 242: E384 (1982).

6. Devaskar, U., Magyar, D., Fridshal, D., Buster, J., and Nathaniels: Development of responsiveness of dispersed rabbit adrenal cortical cells to synthetic ACTH and MSH. Endocrinology, 107: 809 (1980).

7. Dixon, T. F. and Purdom, M.: Serum 5-Nucleotidase. J. Clin. Pathol., 7: 341 (1954).

8. Fantus, I. G., Ryan, J., Hizuka, N., and Gorden, P.: The effect of glucocorticoids on the insulin receptor: An in vivo and in vitro study. J. Clin. Endocrinol. Metab., 52: 953 (1981).

9. Fisher, D. A. and Klein, A. H.: Thyroid development and disorders of thyroid function in the newborn. N. Engl. J. Med., 305: 702 (1981).

10. Ganguli, S., Voina, S., Velayo, N., Devaskar, U., and Sperling, M.: Ontogenesis of insulin and glucagon receptors and adenylate cyclase in rabbit fetal plasma membrane. Diabetes, 29 (Suppl 2): 102A (1980).

11. Heise, H., Joost, H. G., and Hasselblatt, A.: Insulin binding and response to insulin of adipocytes from thyroxine treated rats. Endocrinology, 110: 955 (1982).

12. Kahn, C. R., Goldfine, I. D., Neville, Jr., D. M., and Demeyts, P.: Alteration in insulin binding induced by changes in vivo in the levels of glucocorticoids and growth hormone. Endocrinology, 103: 1054 (1978).

13. Kaplan, S. A.: The insulin receptor. Pediatr. Res. 15: 1156 (1981)

14. Liggins, G. C. and Hoire, R. N.: A controlled trial of antepartum glucocorticoid treatment for prevention of the respiratory distress syndrome in premature infants. Pediatrics, 50:515 (1972).

15. Lowry, O. H., Rosenbrough, N. J., Farr, A. L., and Randell, R. J.: Protein measurement in folin-phenol reagent. J. Biol. Chem., 193: 265 (1951).

16. Neufeld, N. D., Kaplan, S. A., Lippe, B. M., and Scott, M.: Increased monocyte receptor binding of $\left[{ }^{125} \mathrm{~K}\right]$-insulin in infants of gestational diabetic mothers. $\mathrm{J}$. Clin. Endocrinol. Metab., 47: 590 (1978).

17. Neufeld, N. D., Scott, M., and Kaplan, S. A.: Ontogeny of the mammalian insulin receptor: Studies of human and rat fetal liver plasma membranes. Devel. Biol., 78: 151 (1980).

18. Neville, D. M., Jr.: Isolation of an organ specific protein antigen from cell-surface membrane of rat liver. Biochim. Biophys. Acta, 154: 540 (1968).

19. Olefsky, J. M.: Insulin resistance and insulin action: $A n$ in vitro and in vivo perspective. Lilly Lecture 1980. Diabetes, 30: 148 (1981).

20. Olefsky, J. M., Johnson, J., Liu, F., Jen, P., and Reaven, G. M.: The effects of acute and chronic dexamethasone administration on insulin binding to isolated rat hepatocytes and adipocytes. Metabolism, 24: 517 (1975).

21. Rooney, S. A. and Gross, I.: Stimulation of fetal lung choline-phosphate cytidyl transferase activity by glucocorticoids and estrogen in the rabbit in vivo and the rat in vitro. Ann. Rev. Respir. Dis., 119: 354 (1979).

22. Scatchard, G.: The attraction of proteins for small molecules and ions. Ann. N.Y. Acad. Sci., 51: 660 (1949).

23. Shamoon, H., Soman, V., and Sherwin, R. S.: The influence of acute physiological increments of cortisol on fuel metabolism and insulin binding to monocytes in normal humans. J. Clin. Endocrinol. Metab., 50: 495 (1980).

24. Sodoyez, J. C., Goffaux, F. S., Goff, A. G. Zimmerman, A. E., and Arquilla, E. R.: $\left({ }^{127} \mathrm{I}\right)$ or carrier free $\left({ }^{125} \mathrm{I}\right)$ monoiodoinsulin: Preparation, physical, immunological and biological properties and susceptibility to "insulinase" degradation. J. Biol. Chem., 250: 4268 (1975).

25. Sosenko, I. R., Hartig-Beecher, I., and Frantz, I. D.: Cortisol reversal of functional delay of lung maturation in fetuses of diabetic rabbits. J. Appl. Physiol. Respirat. Environ. Exercise Physiol., 49: 971 (1980).

26. Sperling, M. A.: Carbohydrate Metabolism: Glucagon, insulin, somatostatin. In: Tulchinsky, E. E. and Ryan, K. J. (Eds) Fetal-Maternal Endocrinology. pp. 337-354, (W. B. Saunders Co. Philadelphia, 1980).

27. Sperling, M. A., Delamater, P. V., Phelps, D., Fiser, R. H., Oh, W., and Fisher, D. A.: Spontaneous and aminoacid stimulated glucagon secretion in the immediate postnatal period. Relation to glucose and insulin. J. Clin. Invest., 53: 1159 (1974).

28. Sperling, M. A., Ganguli, S., Voina, S., Kaptein, E., and Nicoloff, J. R.: Modulation by thyroid status of the glucagon receptor-adenylate cyclase system in rat liver plasma membranes. Endocrinology, 107: 684 (1980).

29. Stiles, G. L., Stadel, J. M., DeLean, A., and Lefkowitz, R. J.: Hypothyroidism modulates beta adrenergic receptor-adenylate cyclase interactions in rat reticulocytes. J. Clin. Invest., 68: 1450 (1981).

30. Thakur, A. K., Jaffe, M. L., and Rodbard, D.: Graphical analysis of ligand binding systems: Evaluation by Monte Carlo Studies. Anal. Biochem., 107: 279 (1980).

31. Whitsett, J. A., Darovec-Beckerman, C., Adams, K., Pollinger, J., and Howard, N.: Thyroid dependent maturation of $\beta$-Adrenergic receptors in the rat lung. Bioch. Biophys. Res. Comm., 97: 913 (1980).

32. Requests for reprints should be addressed to: Dr. Mark A. Sperling, Division of Endocrinology, Children's Hospital Medical Center, Cincinnati, OH 45229.

33. Supported in part by grants from the USPHS, National Institutes of Health HDI2613, ST 32HD07200, and HD 11725.

34. Received for publication February 24, 1982.

35. Accepted for publication June 1, 1982. 